\title{
sciendo
}

CIVIL AND ENVIRONMENTAL ENGINEERING REPORTS

E-ISSN 2450-8594

CEER 2021; 31 (2): 0030-0042

DOI: 10.2478/ceer-2021-0018

Original Research Article

\section{PROTECTION OF STEEL STRUCTURES WITH PAINT COATINGS IN THE CONTEXT OF ENVIRONMENTAL POLLUTION}

\author{
Marek Henryk DOHOJDA ${ }^{1}$, Beata BACKIEL-BRZOZOWSKA ${ }^{2}$, \\ Bożena DOHOJDA ${ }^{1}$ \\ ${ }^{1}$ Warsaw University of Life Sciences - SGGW, Faculty of Civil and Environmental \\ Engineering, Warsaw, Poland \\ ${ }^{2}$ Bialystok University of Technology, Faculty of Civil Engineering and Environmental \\ Sciences, Białystok, Poland
}

\begin{abstract}
The article presents important problems occurring in the operation of large-size steel structures protected by paint coatings. In our atmospheric conditions, corrosion of steel structures cannot be avoided, even with the use of protective coatings. The problem of environmental pollution with corrosion products and exfoliated paint then appears. When designing corrosion protection, durability of protection is assumed based on environmental corrosivity categories, but in practice degradation of paint coatings can occur much faster. The problem of premature peeling of paint results, among other things, from its faulty application and use. Steel structure repairs are usually carried out comprehensively, and new protection requires the removal of damaged coatings, mainly by sanding. As a result of the mechanical action of the abrasive material, old paints and corrosion products are removed, which results in a very large amount of waste that settles on the adjacent area. Due to the age of paint removed, this waste often contains compounds such as lead, chromium or zinc, which pose a real threat to the natural environment around the renovated buildings. In the article, based on the observations carried out directly on

\footnotetext{
${ }^{1}$ Corresponding author: Warsaw University of Life Sciences - SGGW, Faculty of Civil and Environmental Engineering, Institute of Civil Engineering, e-mail: marek_dohojda@sggw.edu.pl,
} Nowoursynowska 159, 02-776 Warsaw, Poland, tel. (22)5935104
\end{abstract}


the exemplary structures in renovation, the actual scope of the waste emission was determined. This is a contribution to further spectrometric studies to determine the exact area of contamination and to identify heavy metals in the waste arising from the renovation of steel structures with paint coatings.

Keywords: steel structures, corrosion, paint coatings, area, environmental pollution

\section{INTRODUCTION}

Although the economy of the 21 st century is based on knowledge, innovation and quality, awareness of issues related to corrosion protection is quite low. What's worse, basic knowledge is also insufficient among designers and investors, who often disregard this field of the construction industry and treat it as a less important issue. Even in large prestigious steel structure projects, corrosion protection is in many cases poorly designed and constructed $[10,4]$.

Corrosion is one of the phenomena that cannot be completely eliminated but can be significantly reduced. The degradation of materials caused by corrosion can be effectively reduced, mainly through the use of appropriate protection methods and selection of materials [18].

Economic losses caused by corrosion are still increasing. Total direct and indirect corrosion costs in Poland are estimated at $6-8 \%$ of GDP. The costs of steel structures corrosion are not specified, but it can be assumed that they are significant [6]. Direct losses are costs resulting from premature destruction of corroded structural elements, removal of damages and consequences of possible failures, repairs resulting from corrosion damage. Indirect losses, more difficult to estimate, are equivalent to all other negative economic and social effects caused by this phenomenon.

Corrosion prevention of steel structures is a technological, design and implementation process. Corrosion protection methods are developed, improved and adapted to the requirements of sustainable development [11].

Coal steels commonly used in construction extremely easy corrode in our atmospheric conditions [19]. Structures and buildings made of this material require protection because of their safety and aesthetics [10]. The most common way of protection is by applying layers of undercoat and topcoat paints. Protective paint systems require periodic inspections, renovations, repairs, removal and replacement of damaged coatings [12].

Nowadays, the biggest danger for the natural environment surrounding large steel structures are peeling paint and corrosion products, which get into the soil or surface waters. The problem is very important, because there are many steel structures that are maintained and repaired in our public space. During the removal of damaged painting layers by mechanical, chemical or thermal methods, the largest emission of waste to the environment takes place [7]. Taking care of social 
welfare and environmental protection, zones endangered by pollution with corrosion products and old painting materials should be designated. Determining endangered zones will enable the preparation of appropriate methods for reclamation of contaminated areas.

\section{MATERIALS}

\section{Properties and application of structural steel}

Steel is an iron-carbon alloy (the carbon content does not exceed $2.11 \%$ ), heat and plastic treated. Carbon in steel most often occurs in the form of lamellar perlite. With increased carbon content, there is cementite surrounded by ferrite grains. In Poland, steel is defined in accordance with PN-EN 10020 as a material containing more iron than any other element, with a carbon content generally less than $2 \%$ (by mass) and containing other elements [10]. Due to the chemical composition and the share of individual alloying elements various types of steel are distinguished.

Steel is obtained from pig iron in modern metallurgical installations - using converter, arc and vacuum furnaces, which allow obtaining high quality material. The primary metallurgical product is cast steel (e.g. in the form of billets or slabs), which is processed into steel by plastic forming. Steel metallurgical products include round, square or hexagonal bars, round tubes, closed and open profiles (flat bars, angle bars, channel bars, tee bars ) and sheets.

Steel is a metal susceptible to corrosion in atmospheric and water environment. For the purpose of steel refining, admixtures of other elements (alloy steels) are used, as well as galvanizing processes to reduce corrosion susceptibility. An example is stainless steels, characterized by resistance to corrosion in water and the action of many chemical compounds.

Modern steel is a material with a practically uniform structure and chemical composition. Its properties mainly depend on the percentage of carbon, alloying elements as well as heat and plastic treatment. The carbon content has a large impact on the typical mechanical and technological features of steel, such as tensile and compressive strength, elasticity, plasticity, ductility, impact strength, weldability and hardness.

Steel used in buildings is referred to as structural steel. Structural steels differ in their chemical composition, and therefore also in physical and mechanical properties [9].

\section{Mechanical properties of steel}

Considering the use of carbon steel for structural design, the main characteristics of this material are mechanical properties. Steel strength and quality are 
determined by such basic features as: tensile strength, yield strength, ductility and fracture toughness.

Structural steel is widely used in building constructions, as well as for the production of machinery and vehicles. Considering the conditions under which steel will work, the appropriate type should be selected. Medium carbon steels with the average minimum carbon content of $0.25 \%$ are most commonly used. Structural steel must be sufficiently strong and plastic, which can be obtained in the hardening process and after adding appropriate additives, such as chromium, magnesium, nickel, molybdenum. Such additives increase the hardenability of steel, however they pose a threat to the environment with their emission caused, for example, by corrosive processes [2, 3].

\section{Physical properties of steel}

The physical properties of carbon steel include density of $\rho=7850 \mathrm{~kg} / \mathrm{m}^{3}$, thermal expansion $\alpha=12 \times 10^{-6} / \mathrm{K}$, Poisson's coefficient $v=0.3$ and thermal conductivity $\lambda=58 \mathrm{~W} /(\mathrm{m} \cdot \mathrm{K})$.

\section{Corrosion as a phenomenon favoring delamination of protective coatings}

Corrosion is a process of gradual destruction of materials, occurring on their surface under the influence of the surrounding environment. Depending on the type of material and environmental impacts, the dominant processes have chemical, electrochemical, microbiological or physical character (e.g. melting and other phase transformations, damage by UV radiation).

The term "corrosion" is used to refer to the destruction of the structure of materials, in our case metals. The rate of corrosive destruction of multi-component structures depends on the type of materials in the connected elements, methods of joining and many other factors.

Corrosion is a natural process for steel. Normal carbon steel reacts with oxygen in the air, which creates a layer of iron oxide on the steel surface. This surface is porous and allows further oxidation of the steel, causing the "rust" effect. In other words, corrosion is the gradual destruction of metal and non-metal materials under the influence of chemical and electrochemical environmental impact, as a result of which the condition and properties of the material change.

\section{Types of corrosion}

Corrosion is divided into the following types depending on the mechanism of processes:

- chemical corrosion - occurring in dry gases and liquids that don't conduct electricity (non-electrolytes), liquid organic substances are an example of such a liquid. According to the European Standard "Corrosion of metals and alloys, basic 
terms and definitions" chemical corrosion is "corrosion during which no electrochemical processes occur" $[15,11]$.

- electrochemical corrosion - occurring in aqueous solutions such as sea and fresh water, in moist soils and gases, and thus in electrolyte environments. According to the European Standard "Corrosion of metals and alloys, basic terms and definitions" electrochemical corrosion is "corrosion during which at least one anode reaction and one cathode reaction occurs".

The effect of corrosive processes is the destruction of the metal, which is mainly observed on surfaces in the form of accumulation of solid reaction products, e.g. oxides, rust, scale [14]. If the reaction products fall off the metal substrate, unevenness of the originally smooth surface or pits are observed. It favors the degradation of steel protective layers, mainly paint coatings. In addition, products (metal ions) soluble in a corrosive environment may be formed and pollute the environment.

\section{Corrosivity categories - environment aggressivity}

The procedures of the Road and Bridge Research Institute (RBRI) provide for appropriate protection systems for steel surfaces for the specific environmental corrosivity categories. Corrosivity categories according to PN-EN ISO 12944-2 are given in Table 1 .

Table 1. Corrosivity categories according to PN-EN ISO 12944-2 [11]

\begin{tabular}{|c|c|c|c|}
\hline \multirow{2}{*}{\multicolumn{2}{|c|}{$\begin{array}{l}\text { Corrosivity } \\
\text { categories }\end{array}$}} & \multicolumn{2}{|c|}{ Examples of typical environments in temperate climate (informative only) } \\
\hline & & Interior & Exterior \\
\hline $\mathrm{C} 1$ & very low & $\begin{array}{l}\text { Heated buildings with clean atmospheres, e.g. } \\
\text { offices, shops, schools, hotels. }\end{array}$ & Not applicable \\
\hline $\mathrm{C} 2$ & low & $\begin{array}{l}\text { Unheated buildings where condensation may } \\
\text { occur, e.g. warehouses, sports halls. }\end{array}$ & $\begin{array}{l}\text { Atmospheres slightly polluted. } \\
\text { Mainly rural areas. }\end{array}$ \\
\hline $\mathrm{C} 3$ & medium & $\begin{array}{l}\text { Production rooms with high humidity and } \\
\text { some air pollution, e.g. food processing } \\
\text { plants, laundries, breweries, dairies. }\end{array}$ & $\begin{array}{l}\text { Urban and industrial atmospheres, } \\
\text { average sulfur oxide (IV) pollution. } \\
\text { Coastal areas with low salinity. }\end{array}$ \\
\hline $\mathrm{C} 4$ & high & $\begin{array}{l}\text { Chemical plants, swimming pools, ship and } \\
\text { boat repair yards. }\end{array}$ & $\begin{array}{l}\text { Industrial areas and coastal areas } \\
\text { with moderate salinity. }\end{array}$ \\
\hline $\mathrm{C} 5$ & very high & $\begin{array}{l}\text { Buildings or areas with almost permanent } \\
\text { condensation and high pollution. }\end{array}$ & $\begin{array}{l}\text { Industrial areas with high humidity } \\
\text { and aggressive atmosphere and } \\
\text { coastal areas with high salinity }\end{array}$ \\
\hline $\mathrm{CX}$ & extreme & $\begin{array}{l}\text { Industrial areas with extreme humidity and } \\
\text { aggressive atmosphere. }\end{array}$ & $\begin{array}{l}\text { Offshore areas with high salinity and } \\
\text { industrial areas with extreme } \\
\text { humidity and aggressive atmosphere } \\
\text { and sub-tropical and tropical } \\
\text { atmospheres. }\end{array}$ \\
\hline
\end{tabular}


For large steel engineering structures, such as power pylons, bridges or GSM steel towers, corrosivity classes from $\mathrm{C} 3$ to $\mathrm{CX}$, and for wind farm components and oil drilling rigs the highest corrosion class $\mathrm{CX}$ are adopted.

\section{Paint protective coatings}

Paint protective coatings are used as permanent (in the assumed period) or temporary corrosion protection [20]. They can be implemented as single or multilayer [16]. Multi-layer paint coatings include undercoat layer (primer), intermediate layers and a top layer. Coatings are made of paints, enamels and varnishes. Enamels have fillers, pigments and varnish binder in their composition. However, in relation to paints, quantity of those component is much smaller. Varnishes are made of solutions of binders in various solvents. Paints consist of pigments, fillers and a binder.

Due to the properties, the following types of paints are distinguished:

- insulating,

- passivating,

- sacrificial.

Undercoat paints are used as periodic protection, e.g. during assembly of the structure, or as a primer to which another paint coat will be applied.

Insulating undercoats separate the surface at risk of corrosion from mechanical impacts and electrically isolate it from the environment. In their composition they have inert pigments, such as zinc white, titanium white and iron oxide.

Sacrificial undercoats contain metal in the form of dust, with smaller potential than the potential of the protected metal. For example, aluminum or zinc in the form of dust is used to protect iron alloys.

Passive undercoats have an insulating and passivating effect, forming a layer of metal oxides and salts on its surface, which prevents corrosion. Strong oxidizer are used as pigments in these paints: lead minium, lead chromate and zinc chromate.

Among the primer paints, minium based paints are still used. Minium (red lead) paints have long been used as anti-corrosive preparations, used for the first painting of steel and cast iron elements and sheets. The anti-corrosive effect of minium paint is based on the so-called passivation, consisting of the formation of a tight oxide film on the metal surface isolating it from the corrosive environment. The main disadvantage of minium paints is the fact that they contain lead, which is a poisonous substance.

\section{Methods of paint coating application}

When choosing the method of applying paint coatings, one should know as much as possible about the covered element. The most important information is: size and shape of the element and the condition of the surface to be covered [11]. 
Bożena DOHOJDA

In the case of large-size steel structures, the volume of painting work is defined as total surface painted with primer and topcoat paints. The thickness of individual paint coatings and the technique of their application are specified in the Technical Approval of the Institute of Road and Bridge Construction. The total thickness of dry coatings should be $240-320 \mu \mathrm{m}$. Fig. 1 shows the classification of techniques for applying paint coatings.

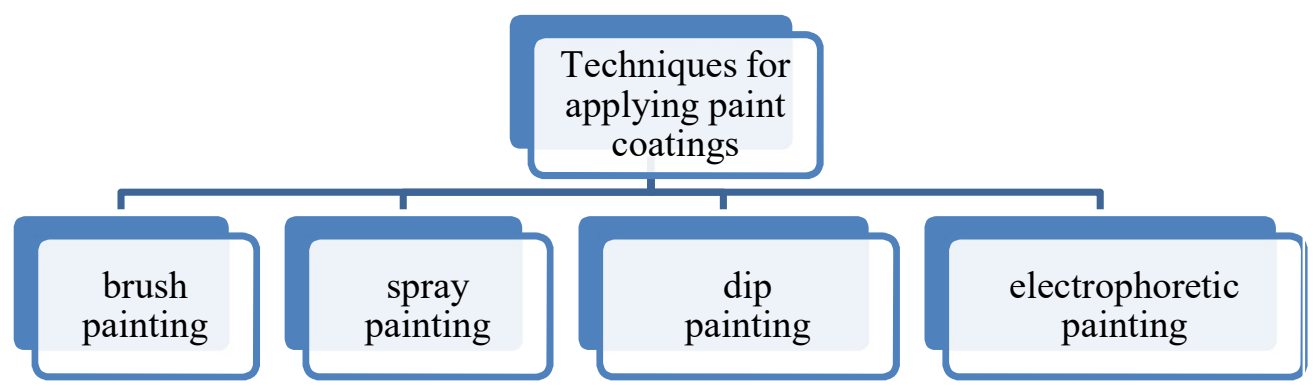

Fig. 1. Classification of techniques for applying paint coatings

All work on the application of paint coatings should be carried out in accordance with the guidelines set out in the detailed technical specifications prepared for the project.

\section{Defects of paint coatings}

Defects arising at the stage of applying the paint layers and during the operation of the structure promote delamination of the coatings, which causes emissions of pollutants into the environment.

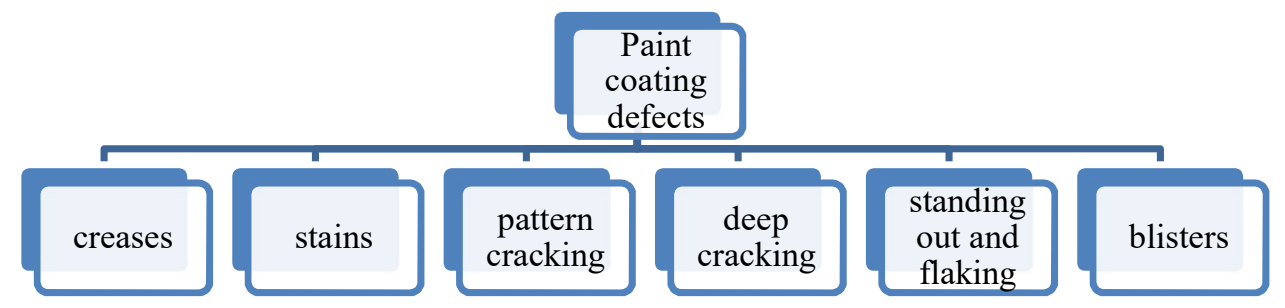

Fig. 2. Types of paint coating defects

Defects arising at the stage of applying the paint layers and during the operation of the structure promote delamination of the coatings, which causes emissions of pollutants into the environment.

Defects in paint coatings are caused by the application technology and operating conditions. Fig. 2 shows the types of the most common defects. Creases are the result of drying the paint coating, which is too thick, and the only method to 
remove this defect is to re-apply the correct thickness. Stains are only an aesthetic defect, which does not matter in terms of metal protection. They are formed when painting vertical surfaces with low viscosity paint. Fragility and deep or pattern cracking can be caused by a change in the plastic properties of the painting material due to high temperature, UV radiation and other atmospheric factors. Detachment and peeling of coatings is caused by improper preparation of the surface covered with a paint coating [8]. Blisters appear for various reasons: poor surface preparation, too thick layers, moisture in the paint coating, undercoating corrosion.

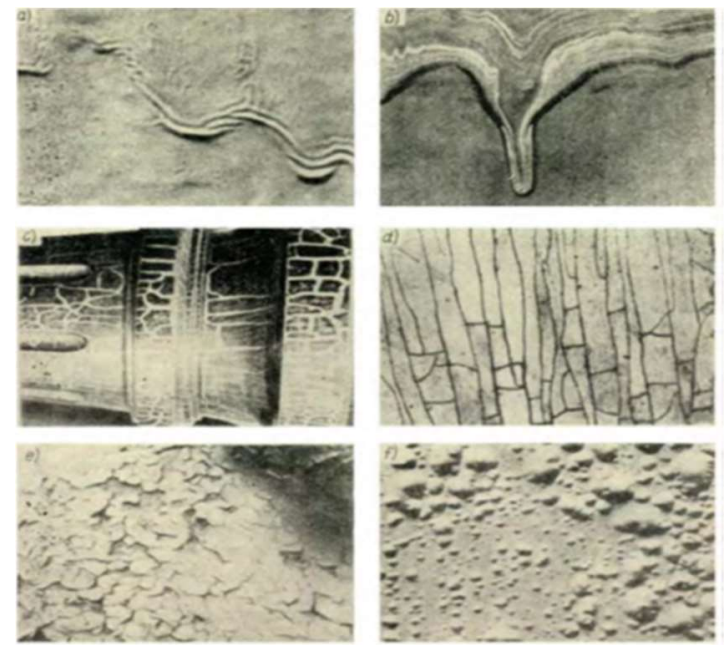

Fig. 3. Defects of paint coatings [18]:

a) crease, b) stain, c) pattern cracking, d) deep cracking,

e) standing out and flaking, f) blisters

\section{Removal of old paint coatings from steel surfaces}

Painting is one of the most popular methods of protecting various surfaces, not only has a protective but also decorative function. However, to achieve a good adhesion of paint, the painted surface has to be properly prepared. Old coatings are becoming a particularly big challenge, which in many cases has to be completely removed before new painting can be started.

The most popular method to remove paint coatings is mechanical scraping. This is done manually using sandpaper, brushes and using electric grinding machines. The most effective mechanical method is sandblasting, which consists in applying fine-grained abrasive at sufficiently high pressure.

Chemical paint removal involves covering with a special preparation that causes swelling and melting of an old coating, which can then be easily removed with a spatula or a water jet. This method it requires special precautions, therefore it is 
not usually used for preparation of large areas. It works very well with more complicated details that would be difficult to prepare with other methods.

For thermal paint removal, electric heat guns are used to produce a stream of hot air. Under the influence of temperature, the paint swells, which makes it relatively easy to scrape with a spatula. This method is only effective with certain types of paints. In addition, it requires caution so as not to damage the prepared surface. As mentioned earlier, the most common method of removing old coatings is abrasive machining. In workshop conditions, it is possible to carry out work in specialized chambers, equipped with extractors enabling the removal of dust generated. All the waste should be utilized in a proper way. It is usually burned in specialized incineration plants. Renovation works performed at the facilities require the use of covers to reduce the emission of pollutants. However, in practice, a significant proportion of pollution ends up in the environment.

It should be emphasized, that depending on the type and chemical composition of the coating, each waste will pose a specific threat to the environment, and thus also to human health. Metallic poisons accumulate in the body to varying degrees and cause characteristic diseases (lead poisoning, zinc fever, cancer) $[1,13,17]$. Some paint ingredients can also cause allergies.

\section{RESULTS}

\section{Technical aspects of environment pollution}

During the renovation of large engineering steel structures, mechanical removal of paint layers poses a great threat to the environment. Assuming the average thickness of paint coatings at $320 \mu \mathrm{m}$ (in accordance with RBRI guidelines) and the density of paints used for applying coatings, securing within $1.4-2.6 \mathrm{~kg} / \mathrm{dm}^{3}$, from $1 \mathrm{~m}^{2}$ of the structure surface we get waste weighing about $0.8 \mathrm{~kg}$, not including corrosion products. For the renovation of large structures, such as power pylons and steel bridges, the total mass of pollutants can reach tens or even hundreds of kilograms. Removing paint coatings mechanically causes spraying of paint particles in the vicinity of the structure, causing environmental pollution. Therefore, it is very important to designate a zone exposed to direct pollution during renovation work.

Based on the observations of the renovation works carried out on a number of structures, the authors established a zone exposed to direct pollution caused by the mechanical removal of paint. The proposal for determining the pollution zone is presented below on the example of two typical objects. 


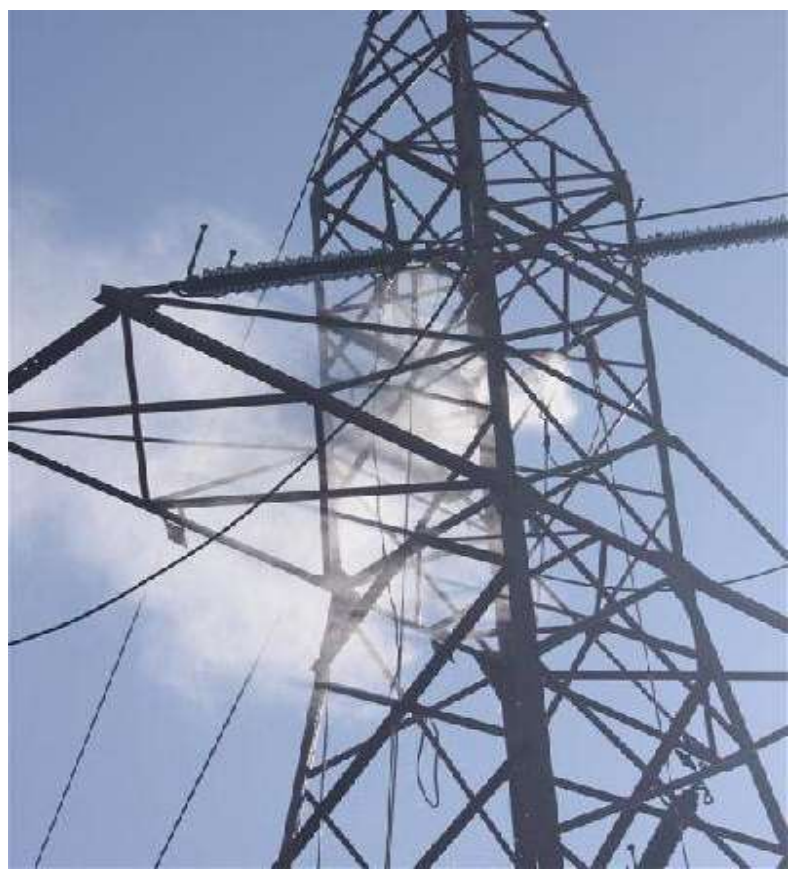

Fig. 4. Removing protective layers by sandblasting the steel pole of power line $400 \mathrm{kV}$

Fig. 4 shows dusty pollution arising when sandblasting the steel pole of power line. Based on the visual assessment, the area covered with dust was determined, indicating the zone of direct pollution in the area the pole. The observations show that such a zone can be established within 15 meters outside the pole contour, as shown in Fig. 5.

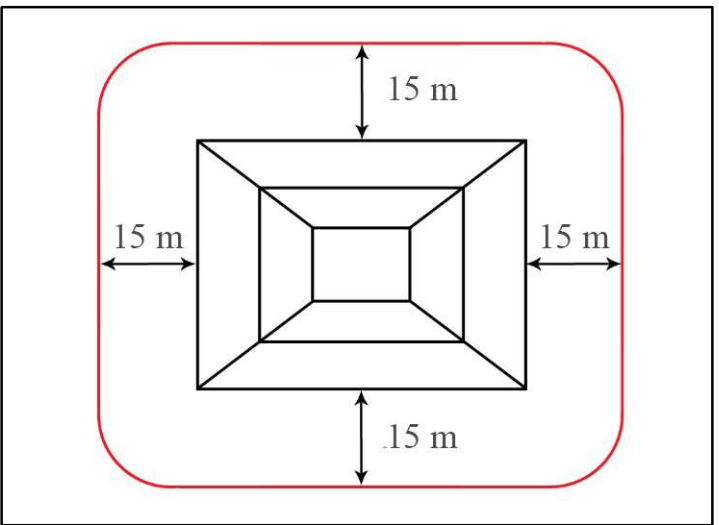

Fig. 5. Diagram of the area directly exposed to waste pollution after sandblasting the $400 \mathrm{kV}$ pole structure. 
For bridge structures, the observed area of impact of pollution caused by sandblasting was smaller than for power poles due to their lower height and the use of curtains limiting the distribution of dust [5]. An example of a steel bridge during a renovation with protecting curtains is shown in Fig. 6. However, in the absence of curtains, the impact area is often much larger. It may even exceed the area specified for power poles. Moreover, it was observed that the waste after sandblasting the steel bridge in Puławy posed a threat to people on the fairway.

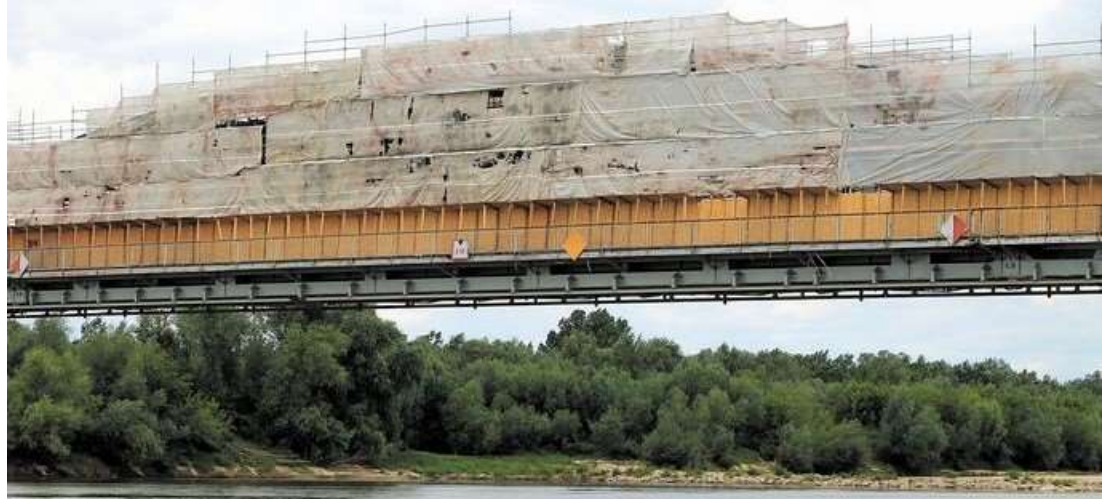

Fig. 6. View of the steel bridge during renovation - sandblasting

As a result of observations and measurements carried out for bridge structures, the area endangered by pollution was determined for min. $10 \mathrm{~m}$ outside the external dimensions of the construction, according to the diagram proposed by the authors shown on Fig. 7.

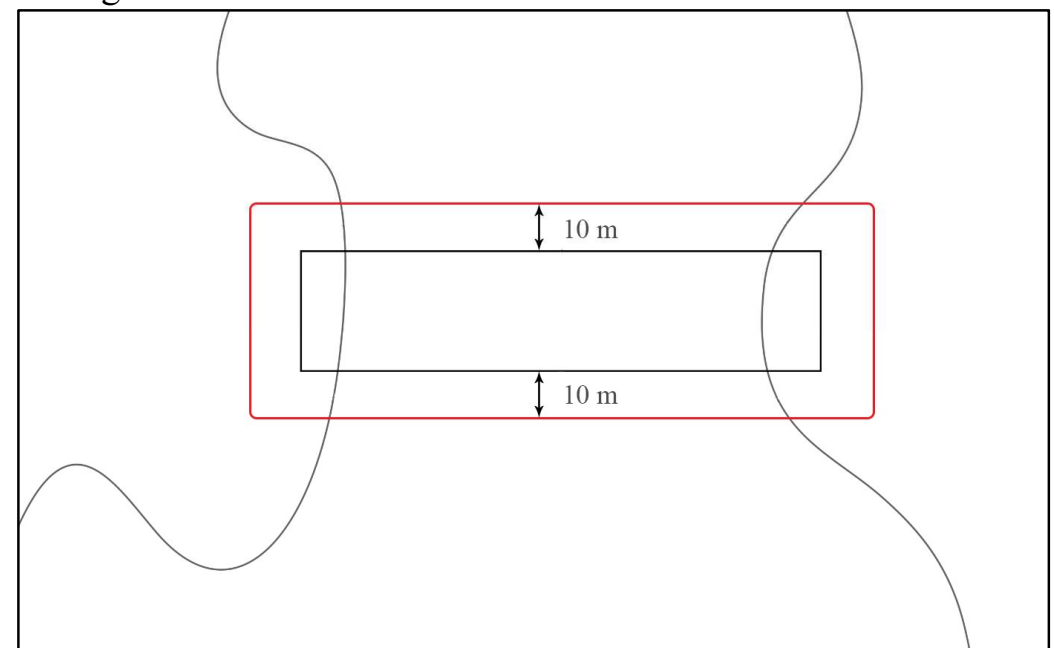

Fig. 7. Top view - diagram of the area directly threatened by waste cover after sandblasting the bridge structure 


\section{SUMMARY}

The issue of renovation works on large-size steel structures discussed in the article indicates the problem of environmental pollution. Depending on the location of the structure, appropriate category of corrosivity of the atmosphere is assumed to assure the proper protection against corrosion. Incorrect recognition of the corrosivity category may result in premature destruction of the protective paint layers, which in extreme cases may lead to failure of the structure. Accurate knowledge and ability to recognize the type of steel corrosion is necessary when designing a structure, and later during its operation. Appropriate selection of protective layers for a particular type of engineering structures will allow long operation while reducing environmental pollution. The designer, having a wide range of methods, should choose the most effective way of protection which is also the most economical. Assuming that the pollution generated in the renovation process is carried by air movement and gravity, all the waste can end up in the vicinity of the structure, causing undesirable environmental and health effects. The assessment of this effect is yet another scientific issue that will be supported by detailed research on the identification of harmful pollutants and their impact on the environment.

\section{REFERENCES}

1. Boroń, M, Dobrakowski, M, Chmielewski, J, Gworek, B, KorzonekSzlacheta, I, Kiełtucki, J, Szpringer, M and Kasperczyk, S 2018. Aspekty zdrowotne w krótkookresowym narażeniu na ołów. Przemyst Chemiczny, vol. 97.

2. Brokbartold, M, Wischermann, M and Marschner, B 2012, Plant Availability and Uptake of Lead, Zinc, and Cadmium in Soils Contaminated with Anticorrosion Paint from Pylons in Comparison to Heavy Metal Contaminated Urban Soils. Water Air Soil Pollut 223, 199-213.

3. Brokbartold, M, Grupe, M and Marschner, B 2012. Effectiveness of different soil amendments to reduce the $\mathrm{Pb}$ and $\mathrm{Zn}$ extractability and plant uptake in soils contaminated by anticorrosion paints beneath pylons. Journal of Plant Nutrition and Soil Science volume 175 issue 3, 443-455.

4. Jaczewski, M 2013. Expert's eye on corrosion protection projects and technical specifications. Ochrona przed Korozja 6, 266-268.

5. Kamiński, T, Bień, J, Hildebrand, M, Kużawa, M and Rabiega, J 2016. Ocena kondycji mostu kratownicowego przez Wiste $w$ Pulawach. Duze mosty wieloprzęstowe. Projektowanie, technologie budowy, monitoring. Wrocław 29-30 listopada 2016. DWE, Wrocław 2016. 
6. Kobus, J and Lutze, R 2016. Evaluation of economic effects of corrosion using life cycle costs methodology. Autobusy: technika, eksploatacja, systemy transportowe R 17 6, 210-215.

7. Koprowicz, M Rocznik 2010. Wybrane ekologiczne aspekty wykonywania zabezpieczeń antykorozyjnych. Ochrona przed korozją 9, 438-439.

8. Kowalski, D 2017. Problems with anticorrosion coatings of bridge equipment element. Corrosion Protection 60, no. 3, 65-68.

9. Kozłowski, J 2015. EN 1090 i jej wymagania w zakresie zabezpieczenia antykorozyjnego stalowych konstrukcji spawanych. Przeglad Spawalnictwa Welding Technology Review 87, No 5, 64-69.

10. Maciejewski, A 2015. Ochrona przed korozją elementów stalowych (metalowych) występujących w infrastrukturze miejskiej. Inżynier 90.

11. Możaryn, T, Wójtowicz, M and Strąk, A 2016. Korozja i zabezpieczenie konstrukcji stalowych Część 1. Korozja stali. Instytut Techniki Budowlanej, Przeglad Budowlany 6, 45-52.

12. Możaryn, T, Wójtowicz, M and Strąk, A 2016. Korozja i zabezpieczanie konstrukcji stalowych. Cz. 2 - Zabezpieczanie przeciwkorozyjne. Przeglad Budowlany 7-8, 60-66.

13. Pakulska, D and Czerczak, S 2017. Zagrożenia zdrowotne wynikające z narażenia na cynk i jego związki nieorganiczne w przemyśle. Medycyna Pracy 68, no.6, 779-794.

14. PN-EN ISO 9223. Korozja metali i stopów - Korozyjność atmosfer Klasyfikacja, określanie i ocena.

15. PN-EN ISO 8044:2015-12. Podstawowe terminy $i$ definicje.

16. PN-EN ISO 12944-5. Farby i lakiery. Ochrona przed korozja konstrukcji stalowych za pomoca ochronnych systemów malarskich.

17. Rorbach-Dolata, A, Piwowar, A and Marchewka, Z 2016. Ekspozycja na metale ciężkie a ryzyko raka pęcherza moczowego w Polsce i na świecie fakty znane, ale wciąż niedoceniane. Hygeia Public Health 51, no. 4, 343-349.

18. Surowska, B 2009. Wybrane zagadnienia z korozji i ochrony przed korozja. Politechnika Lubelska.

19. Zubielewicz, M and Langer, E 2019. News in the field of coating materials. Corrosion Protection 2019 63, nr 1, 4-7.

20. Zubielewicz, M 2012. Powłoki malarskie jako zabezpieczenie antykorozyjne stalowych drogowych konstrukcji mostowych. Drogi: budownictwo infrastrukturalne $\mathrm{Nr}$ 7-8 (8), 46-55. 